\title{
A Conversation with EBSCO's Steve O'Dell
}

$\mathrm{F}$ rom time to time we're all visited by representatives from various vendors promoting new products or keeping lines of communication open. I often take these opportunities to try to get a sense of the vendor's perspective of the information industry.

Recently, I was visited by Steve O’Dell from EBSCO. Steve has been with EBSCO for five years as a sales representative in the academic, medical, corporate, school, and regional public library markets. His territory includes North Carolina, South Carolina and Virginia. Steve and I always have interesting discussions about the state of the library market so I thought it might be interesting if I shared a portion of these conversations with North Carolina Libraries online readers. Although this interview was conducted in November 2008 after Steve's visit it covers the topics of our discussion.

\section{How did you get involved in the library industry?}

Steve O'Dell: I initially joined EBSCO in response to an employment ad, and upon speaking with an EBSCO corporate recruiter, I became immediately interested in the position. Prior to joining EBSCO, I worked for West Group as a law firm representative calling on four of the five law school libraries in North Carolina. Because I enjoyed my library customers so much in this position, I knew that I would be very interested in calling on libraries exclusively in accordance with the EBSCO job description. Going to work for EBSCO has been the best career decision that I have made to date, and I am very happy here.

How has the industry evolved since you began?

The biggest evolution that I have witnessed has been the shift from print to electronic, or " $E$ " serials vendors as a whole have seen a complete shift from print (in 1999, EBSCO had $60 \%$ print) to print +online or online-only. (In 2006, only $40 \%$ of EBSCO's serials business was print; $40 \%$ was print + online; and $20 \%$ was online-only). This entire shift has resulted in much more work and many more "hoops to jump through" for both vendors and libraries alike.

\section{What trends are you seeing in the industry?}

I believe the trend is continuing to move toward online. From a publisher standpoint, the shift has been toward the "Big
Deals" and publisher packages. These are replacing a lot of individual subscriptions by giving additional journal access and are securing themselves in long-term deals versus the old cycle of annual evaluations and renewals.

When dealing with inflation and budgets, libraries are finding that, to keep up with the inflation of the packages' contractual obligations, they are having to eliminate titles from other publishers thereby leaving them in situations where subject areas may not be covered as needed and where they are not able to do business with all of their desired publishers. As a result, consideration has been given to getting away from the "Big Deals" to free up funds for collections development.

\section{How does EBSCO decide what collections to create or develop?}

EBSCO often utilizes focus groups and solicits feedback from the field regarding collections, subject gaps, and/or demands for new subjects. After analyzing the findings from these discovery venues, and considering the relative costs, we proceed as long as we think there will be win-win results.

Vendors are sometimes referred to as the "dark side" by librarians. Do you feel this is true? Do you have an adversarial relationship with any library, or is this just a running joke among librarians?

At EBSCO, we view our library customers as our "partners." We truly value these relationships, and our focus is to provide a superior suite of value-added products and services to help library staff with the many tasks and challenges associated with E-Access and E-Management.

I have never heard reference made to EBSCO as the "dark side" of libraries.

Some librarians are worried EBSCO and several of the other larger companies are growing too big and forcing all other companies out of business. Can you talk about the recent merger of so many major publishers/providers?

I think that these types of concerns exist in all types of industries today. Personally, I feel that competition is good for the market as long as the competition is comparable. That said, there do seem to be many organizations today that are 
not well grounded with effective ownership/management and not run as efficiently as today's economy demands. EBSCO's role in business, similar to that of libraries in general, is one of adaptability. If a company can adapt as market demands change, it will survive. If a company cannot adapt, it will end up finding a way out of business.

As far as serials management and database companies, this segment of the market has been fairly stable given that most that have historically existed still remain. The majority of mergers that have taken place in our industry seem to have mainly involved publishers. As to why these mergers and acquisitions continue to occur, there appears to be a wide variety of reasons that will likely remain a trend in these economic times.

\section{What's the future look like? What services will be available?}

I think that we are already getting the 35,000-foot view of the future today. The whole issue going forward will be about access for the end user and management for the library staff.
Since most of the access suite of products that have been demanded in the market have already been developed, I feel that the trends include testing the various services offered by the different providers. Access will also always be driven by and proportionate to advances in technology, i.e., the way, method, and devices by which content is delivered. We will also continue to see Web interface enhancements through new Web technologies and efficiencies.

The management of electronic resources is what most library staff is struggling with currently. Our view at EBSCO is that, as part of the serials supply chain, we will continue to maintain the level and accuracy of information that we obtain and provide in order to continue to partner with libraries and help to satisfy their needs. The realization today is that the number of library staff is not increasing, nor will it likely increase in the future, yet the tasks required by e-resource management are greater and more involved than that in the print world of the past. Companies, such as EBSCO, that can help with, or better yet, perform these additional duties and tasks will stand the test of time as the providers of the most beneficial products and services of the future.

\section{North Carolina Libraries}

Official Publication of the North Carolina Library Association ISSN 0029-2540

The subscription cost to North Carolina Libraries is $\$ 50 / y r$.

All quarterly issues are available online free-of-charge at http://www.nclaonline.org/NCL.

Back issues are available from the North Carolina Library Association office at 1811 Capital Blvd., Raleigh, NC 27604, for $\$ 8$ an issue for those years prior to going online in 2002 , or $\$ 50$ for the annual print compilation beginning with

Vol. 60 (2002). 